\title{
ANALISIS KEMAMPUAN PEMAHAMAN MATEMATIS SISWA DALAM MENYELESAIKAN SOAL PERBANDINGAN DI KELAS VII SMP
}

\author{
Utin Desy Susiaty ${ }^{1 *}$, Rahman Haryadi ${ }^{2}$ \\ ${ }^{1}$ Program Studi Pendidikan Matematika Fakultas Pendidikan MIPA dan Teknologi IKIP PGRI \\ Pontianak, Jalan Ampera Nomor 88 Pontianak Kalimantan Barat Indonesia \\ *d3or4f4ty4@gmail.com
}

\section{Received: 1 September 2019 Accepted: 1 Desember 2019 Published: 31 Desember 2019}

\begin{abstract}
Abstrak
Tujuan dalam penelitian ini adalah untuk mengetahui kemampuan pemahaman matematis siswa pada soal perbandingan di kelas VII SMP. Penelitian ini adalah penelitian deskriptif kualitatif. Subjek penelitian adalah 3 siswa kelas VII A SMP Koperasi Pontianak dengan kategori siswa rendah, sedang dan tinggi. Instrumen penelitian yang digunakan adalah soal kemampuan pemahaman matematis dan pedoman wawancara. Setelah pengumpulan data, peneliti menganalisis hasil pengerjaan soal kemampuan pemahaman matematis dan hasil wawancara untuk melihat kemampuan pemahaman matematis siswa. Berdasarkan analisis data dapat disimpulkan bahwa kemampuan pemahaman matematis siswa kelas VII SMP Koperasi Pontianak masih rendah yang ditunjukkan dengan terdapatnya banyak kekeliruan penyelesaian soal kemampuan pemahaman matematis khususnya pada indicator mendefinisikan konsep secara tulisan, merepresentasikan suatu konsep dalam bentuk model, diagram, dan symbol, mengidentifikasikan contoh dan bukan contoh suatu perbandingan serta mengubah suatu bentuk representasi ke bentuk lainnya.
\end{abstract}

Kata kunci: analisis, kemampuan pemahaman matematis, perbandingan

\section{Abstract}

The purpose of this study was to knowed the students matter of understanding ability in class VII of junior high school. This research is a qualitative descriptive study. The research subjects were 3 students of class VII A SMP Koperasi Pontianak with a low, medium and high students. The research instrument used was a matter of the ability to understand mathematics and interview guidelines. After the data was approved, the researchers analyzed the results of the work on the questions of mathematical comprehension ability and the results of interviews to see students' mathematical understanding abilities. Based on data analysis, it can be concluded that the students mathematical understanding ability of class VII SMP Koperasi Pontianak is still low as indicated by the existence of many errors in solving the problem of mathematical comprehension ability, especially on indicators defining concepts in writing, representing concepts in the form of models, diagrams and symbols, identifying examples and not an example of a comparison and changing a form of representation to another form.

Keywords: analysis, mathematical understanding ability, comparison

(C) 2019 LPPM IKIP PGRI Pontianak, Indonesia

\section{PENDAHULUAN}

Pendidikan adalah suatu proses dalam rangka mempengaruhi siswa agar dapat menyesuaikan diri sebaik mungkin terhadap lingkungannya dan dengan demikian akan menimbulkan perubahan dalam dirinya yang memungkinkannya untuk berfungsi secara adekuat dalam kehidupan masyarakat. 
Pengajaran bertugas mengarahkan proses ini agar sasaran dari perubahan itu dapat tercapai sebagaimana yang diinginkan (Hamalik, 2015). Menurut Alan dan Afriansyah (2017) pendidikan merupakan salah satu alat untuk meningkatkan taraf hidup bangsa. Pada dasarnya pendidikan merupakan sebuah upaya untuk meningkatkan kualitas sumber daya manusia (SDM). Pendidikan dapat ditempuh salah satunya di sekolah, dari beberapa mata pelajaran yang di pelajari siswa, matematika merupakan salah satu ilmu yang sangat penting dalam dunia pendidikan.

Jonsson et al (2014) menyatakan bahwa "Basic mathematical competencies include problemsolving abilities (how to solve tasks without knowing a solution method in advance), reasoning ability (the ability to justify choices and conclusions), and conceptual understanding (insights regarding the origin,motivation, meaning, and use of mathematics)". Menurut Wibawa (2017) "Mathematics section of the science studied ranging from elementary, junior high, high school / vocational school even in Higher Education. Mathematics has a characteristic, that has an abstract object. The abstract nature of mathematics makes mathematical material difficult for students to comprehend". Hal ini sejalan dengan pendapat yang dikemukakan oleh Ignatio, et al (2006) menyatakan bahwa "students with mathematics learning difficulties due to their repeated experience of failure are those who present the most maladapted attributional patterns". Dari beberapa pendapat tersebut dapat disimpulkan bahwa dalam pembelajaran matematika diperlukan factor penting yang dapat menjadi jawaban dari semua permasalahan dalam penyelesaian matematika.

Salah satu faktor penting dalam pembelajaran matematika saat ini adalah pentingnya pengembangan kemampuan pemahaman matematis siswa. Kurniadi dan Purwaningrum (2018) menyatakan bahwa masalah yang sangat menonjol yang dihadapi dalam pengajaran matematika umumnya adalah pembelajaran matematika yang tidak efektif. Salah satu akibat dari pembelajaran tersebut diantaranya pengembangan kemampuan pemahaman matematis siswa tidak maksimal. Kemampuan pemahaman matematis adalah pengetahuan siswa terhadap konsep, prinsip, prosedur dan kemampuan siswa menggunakan strategi penyelesaian terhadap suatu masalah yang disajikan. Seseorang yang telah memiliki kemampuan pemahaman matematis berarti orang tersebut telah mengetahui apa yang dipelajarinya, langkah-langkah yang telah dilakukan, dapat menggunakan konsep dalam konteks matematika dan di luar konteks matematika (Wijaya, dkk., 2018, Alan \& Afriansyah, 2017).

Ruseffendi (2006) mengemukakan terdapat tiga macam pemahaman sebagai berikut: a) pengubahan (translation) yaitu mengubah suatu persamaan menjadi suatu grafik, mengubah soal berbentuk kata-kata atau menyatakan suatu situasi menjadi bentuk symbol atau sebaliknya; b) interpretasi (interpretation) yaitu menggunakan konsep-konsep yang tepat dalam menyelesaikan 
soal, mengartikan suatu kesamaan; dan c) ekstrapolasi (extrapolation), yaitu menerapkan konsepkonsep dalam perhitungan matematis, dan memperkirakan kecenderungan suatu diagram.

Beberapa penelitian relevan yaitu yang dilakukan oleh Wijaya, dkk (2018) menyimpukan bahwa kemampuan pemahaman matematis siswa dalam memahami masalah, merencanakan penyelesaian, dan melakukan pengecekan kembali terhadap semua langkah yang telah dikerjakan tergolong sedang. Penelitian yang dilakukan oleh Malihatuddarojah dan Prahmana (2019) menyimpulkan bahwa kesalahan yang ditemui dalam penelitian adalah kesalahan pada variabel, tanda negatif, menyelesaikan bentuk persamaan aljabar, pengoperasian bentuk aljabar, dan penyelesaian bentuk pecahan. Kemudian penelitian yang dilakukan oleh Susiaty, dkk (2017) diperoleh bahwa kesulitan belajar yang dialami oleh mahasiswa dalam mempelajari mata kuliah matematika ekonomi terjadi hanya pada mahasiswa dengan kategori sedang dan rendah saja. Hal ini menunjukkan bahwa penelitian yang terdahulu melakukan analisis untuk menemukan inti permasalahan sehingga dapat ditemukannya suatu solusi atau jawaban dari permasalahan tersebut. Adapun perbedaan dengan penelitian ini adalah peneliti menganalisis kemampuan pemahaman matematis pada siswa sekolah khususnya siswa SMP pada materi perbandingan. Sehingga hasil penelitian ini akan bermanfaat bagi siswa, guru maupun sekolah yang bersangkutan.

Melihat kondisi yang terjadi tersebut, penulis berkeinginan untuk melakukan analisis terhadap kemampuan pemahaman matematis siswa pada soal perbandingan di kelas VII SMP untuk melihat sejauh mana pemahaman siswa terhadap materi perbandingan, serta untuk melihat kesulitan siswa selama proses penyelesaian masalah dalam materi perbandingan. Penelitian ini diharapkan dapat memberikan informasi lebih mendalam kepada pihak terkait dalam menganalisis kemampuan pemahaman matematis siswa khususnya materi perbandingan yang sudah terjadi selama ini di SMP Koperasi Pontianak.

\section{METODE}

Penelitian ini termasuk penelitian deskriptif kualitatif yang bertujuan untuk mengetahui kemampuan pemahaman matematis siswa pada soal perbandingan di kelas VII SMP dalam mempelajari mata pelajaran matematika tahun akademik 2017/2018. Adapun tahap dalam penelitian ini adalah: 1) tahap orientasi atau deskripsi, pada tahap ini peneliti mendeskripsikan hasil belajar siswa kelas VII SMP Koperasi Pontianak berdasarkan hasil wawancara guru dan pengamatan pada pembelajaran sebelumnya untuk memperoleh informasi mengenai kemampuan pemahaman matematis siswa di sekolah tersebut khususnya pada materi perbandingan; 2) tahap reduksi atau focus, pada tahap ini peneliti mereduksi informasi pada tahap pertama dan focus pada pengukuran kemampuan pemahaman matematis siswa kelas VII SMP Koperasi Pontianak dengan memberikan 
soal kemampuan pemahaman matematis berbentuk essay yang sesuai dengan indicator kemampuan pemahaman matematis itu sendiri. Selanjutnya, peneliti melakukan wawancara terhadap subjek penelitian dengan kategori tinggi, sedang dan rendah berdasarkan Tabel 1 untuk mengetahui secara mendalam kemampuan pemahaman matematis siswa yang bersangkutan; 3) tahap selection, pada tahap ini peneliti menguraikan hasil tes kemampuan pemahaman matematis siswa dan wawancara subjek dengan kategori tinggi, sedang dan rendah menjadi lebih terperinci berdasarkan kesalahan dan penyebab kesalahan penyelesaian masalah perbandingan di kelas VII SMP Koperasi Pontianak. Adapun paparan tentang kesalahan dan penyebab kesalahan kemampuan pemahaman matematis dalam penyelesaian masalah perbandingan terfokus pada indicator kemampuan pemahaman matematis sebagai berikut: mendefinisikan konsep secara verbal dan tulisan, mengidentifikasi dan membuat contoh dan bukan contoh, menggunakan model, diagram dan symbol-simbol untuk merepresentasikan suatu konsep, mengubah suatu bentuk representasi ke bentuk representasi lainnya, mengenal berbagai makna dan interpretasi konsep, mengidentifikasi sifat-sifat suatu konsep dan mengenal syarat yang menentukan suatu konsep, serta membandingkan dan membedakan konsepkonsep.

Subjek penelitian dalam penelitian ini adalah 3 siswa kelas VII A SMP Koperasi Pontianak yang mengikuti pembelajaran matematika dengan kategori siswa rendah, sedang dan tinggi. Penentuan subjek ini berdasarkan saran dari guru matematika kelas VII SMP Koperasi Pontianak. Adapun siswa yang menjadi subjek dalam penelitian ini disajikan pada Tabel 1.

Tabel 1. Subjek Penelitian

\begin{tabular}{clcc}
\hline No & Nama Mahasiswa & Hasil Belajar & Kategori \\
\hline 1 & Nurcholia Tiara Dejuani & 85 & Tinggi \\
2 & Jelita Aulia & 60 & Sedang \\
3 & Nirina Rahmadanti & 15 & Rendah
\end{tabular}

Sumber : Hasil Murni Ujian Akhir Semester Ganjil TA 2017/2018.

Teknik pengumpul data dalam penelitian ini adalah teknik pengukuran dan teknik komunikasi langsung dengan alat pengumpul datanya berupa soal kemampuan pemahaman matematis dan pedoman wawancara. Bentuk soal yang digunakan adalah essay sebanyak 5 butir. Soal dan pedoman wawancara yang digunakan dalam penelitian ini telah melalui proses uji kelayakan instrument dan dinyatakan layak digunakan sebagai instrument penelitian. Wawancara dilakukan kepada subjek penelitian yang terdiri dari 3 orang siswa program siswa kelas VII A dengan kategori siswa tinggi, sedang dan rendah berdasarkan hasil murni Ujian Akhir Semester (UAS) Ganjil TA 2017/2018. 
Pada dasarnya bagian ini menjelaskan bagaimana penelitian itu dilakukan. Materi pokok bagian ini adalah rancangan penelitian, populasi dan sampel (subjek penelitian), teknik dan alat pengumpulan data, dan teknik analisis data. Untuk penelitian yang menggunakan alat dan bahan, perlu dituliskan spesifikasi alat dan bahannya.

\section{HASIL DAN PEMBAHASAN}

Berdasarkan hasil analisis jawaban tertulis dan wawancara tiga orang subjek siswa kelas VII SMP Koperasi Pontianak berdasarkan kategori tinggi (S1), sedang (S2) dan rendah S3), maka dapat dipaparkan kemampuan pemahaman matematis siswa kelas VII. Analisis kemampuan pemahaman matematis S1 yaitu melakukan beberapa kesalahan di antaranya: (1) pada soal nomor 2, siswa melakukan kesalahan dalam menentukan jumlah uang yang dimiliki oleh Rani dan Tara dan kesulitannya adalah siswa tidak dapat menentukan jumlah uang yang dimiliki oleh Rani dan Tara. Penyebab kesulitan: siswa memiliki kekeliruan dalam indicator kemampuan pemahaman matematis yaitu merepresentasikan suatu konsep dalam bentuk model, diagram, dan simbol. (2) Pada soal nomor 3, siswa melakukan kesalahan dalam melakukan penyederhanaan pecahan perbandingan. Kesulitannya adalah siswa tidak dapat menentukan penyederhanaan pecahan perbandingan. Penyebab kesulitan: siswa memiliki kekeliruan dalam indicator kemampuan pemahaman matematis yaitu merepresentasikan suatu konsep dalam bentuk model, diagram, dan simbol. (3) Pada soal nomor 5, siswa melakukan kesalahan dalam ketidaktelitian menyederhanakan pecahan perbandingan. Kesulitannya siswa tidak dapat menentukan penyederhanaan pecahan perbandingan. Penyebab kesulitan: siswa memiliki kekeliruan dalam indicator kemampuan pemahaman matematis yaitu mengubah suatu bentuk representasi ke bentuk lainnya. Hal ini ditunjukkan pada Gambar 1.

Selanjutnya untuk mahasiswa dengan kategori sedang S2 berikut analisis kemampuan pemahaman matematisnya: (1) pada soal nomor 1, siswa melakukan kesalahan dalam mengoperasikan perbandingan. Kesulitannya melakukan mengoperasikan perbandingan. Penyebab kesulitan: siswa tidak memahami cara mendefinisikan konsep secara tulisan yang merupakan indicator kemampuan pemahaman matematis. (2) Pada soal nomor 2, siswa melakukan kesalahan dalam mengoperasikan perbandingan. Kesulitannya melakukan mengoperasikan perbandingan. Penyebab kesulitan: siswa tidak memahami indicator kemampuan pemahaman matematis yaitu cara merepresentasikan suatu konsep dalam bentuk model, diagram, dan simbol. (3) Pada soal nomor 3, siswa melakukan kesalahan dalam melakukan penyederhanaan perbandingan dengan dugaan yang dialami siswa melakukan kesalahan dalam melakukan penyederhanaan perbandingan. Penyebab kesulitan: siswa tidak memahami indicator kemampuan pemahaman matematis yaitu cara merepresentasikan suatu konsep dalam bentuk model, diagram, dan simbol. (4) Siswa tidak 
mengerjakan soal no 4 dan 5 dengan dugaan yang dialami siswa masih bingung memahami soal yang berkaitan dengan perbandingan. Penyebab kesulitan: mahasiswa tidak memahami indicator kemampuan pemahaman matematis yaitu konsep soal yang berkaitan dengan mengidentifikasikan contoh dan bukan contoh suatu perbandingan serta mengubah suatu bentuk representasi ke bentuk lainnya. Hal ini ditunjukkan pada Gambar 2.

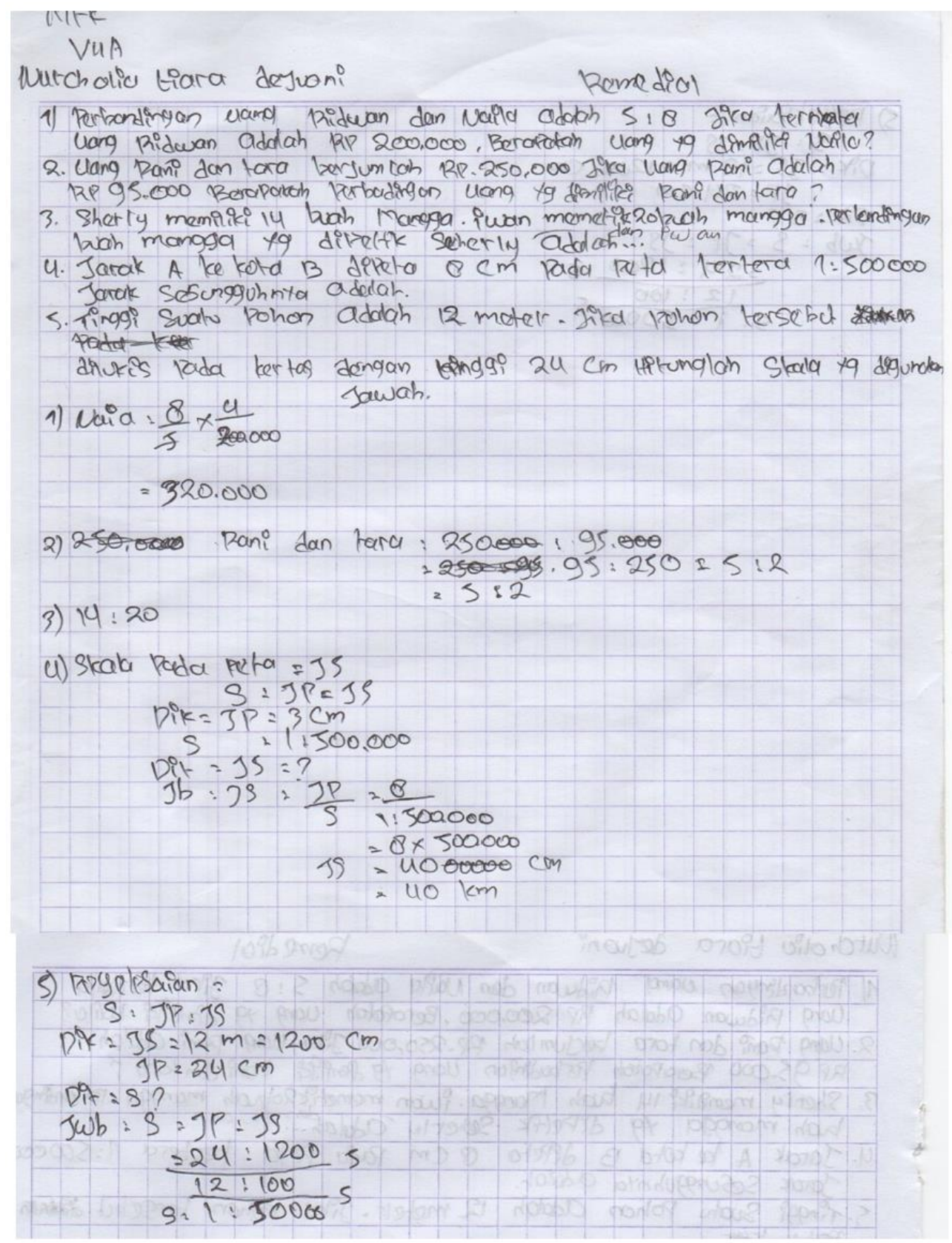

Gambar 1. Hasil jawaban siswa dengan kategori tinggi

Pada siswa dengan kategori rendah S3 melakukan beberapa kesalahan pada indicator kemampuan pemahaman matematis di antaranya: (1) pada soal nomor 1, S3 melakukan kesalahan dalam mengoperasikan perbandingan. Kesulitannya mengoperasikan perbandingan. Penyebab 
kesulitan adalah siswa tidak memahami cara mendefinisikan konsep secara tertulis yang merupakan salah satu indicator kemampuan pemahaman matematis. (2) Pada soal nomor 2, siswa melakukan kesalahan dalam mengoperasikan perbandingan dengan dugaan yang dialami adalah mengoperasikan perbandingan. Penyebab kesulitan: siswa tidak memahami indicator kemampuan pemahaman matematis yaitu cara merepresentasikan suatu konsep dalam bentuk model, diagram dan simbol. (3) Pada soal nomor 3, siswa melakukan kesalahan dalam memahami pertanyaan dari soal dugaan yang dialami adalah kurangnya pemahaman apa yang ditanyakan dalam soal. Penyebab kesulitan: siswa tidak memahami indicator kemampuan pemahaman matematis yaitu cara merepresentasikan suatu konsep dalam bentuk model, diagram dan simbol. (4) Pada soal nomor 4, siswa melakukan kesalahan dalam mengoperasikan perbandingan dan skala dugaan yang dialami kurangnya pemahaman dalam mengoperasikan perbandingan dan skala. Penyebab kesulitan: siswa tidak memahami indicator kemampuan pemahaman matematis yaitu cara merepresentasikan suatu konsep dalam bentuk model, diagram dan symbol. (5) Pada soal nomor 5, siswa melakukan kesalahan dalam mengoperasikan perbandingan dan skaladugaan yang dialami kurangnya pemahaman dalam mengoperasikan perbandingan dan skala. Penyebab kesulitan: siswa tidak memahami indicator kemampuan pemahaman matematis yaitu cara mengubah suatu bentuk representasi ke bentuk lainnya. Hal ini ditunjukkan pada Gambar 3.

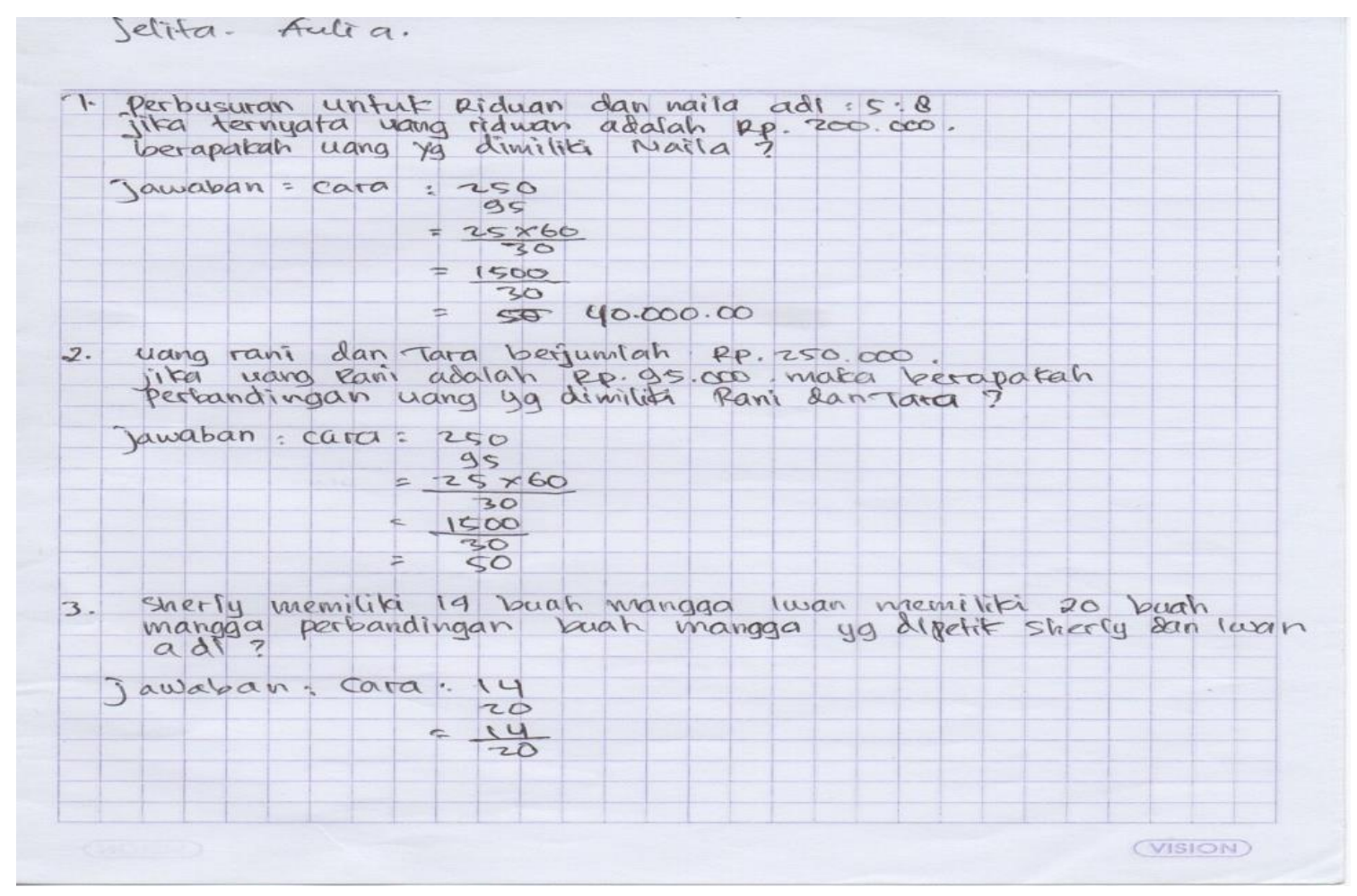

Gambar 2. Hasil jawaban siswa dengan kategori sedang 


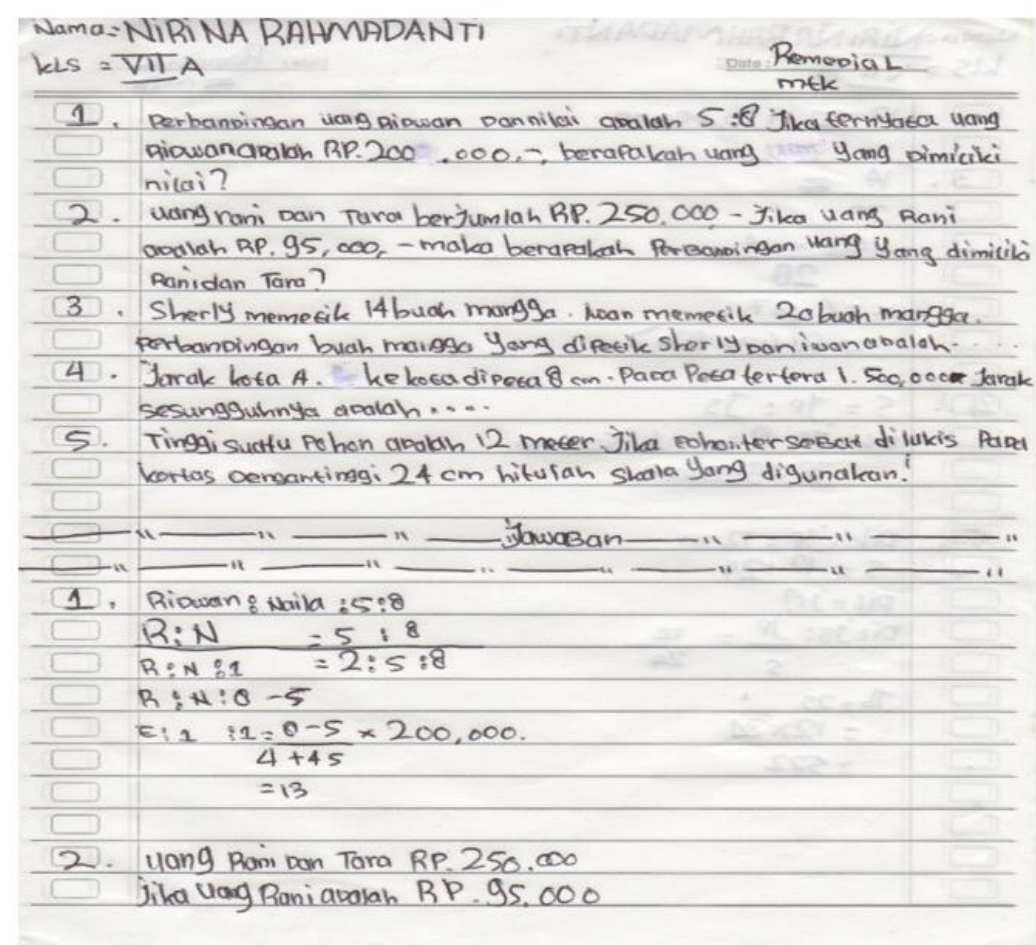

\begin{tabular}{|c|c|c|}
\hline $\begin{array}{l}\text { Nama }=1 \\
\text { KLS }=1\end{array}$ & $\begin{array}{l}\text { NIRINA RAHMAVANTI } \\
\text { VII A }\end{array}$ & $y=$ \\
\hline$\square$ & $12,00150,000,00$ & L \\
\hline$\square$ & 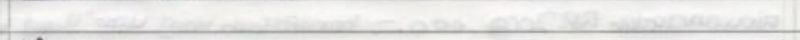 & + \\
\hline 3. & $14 z$ & $\square$ \\
\hline$\square$ & 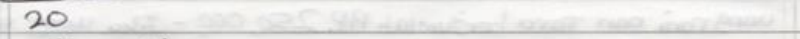 & 20 \\
\hline$\square$ & bes & 18 \\
\hline$\square$ & 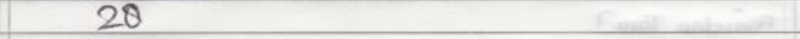 & $\square$ \\
\hline$\square$ & 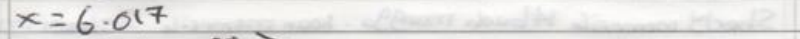 & 8 \\
\hline$\square$ & $=68\langle\operatorname{man} 99 a\rangle$ & $\square$ \\
\hline$\square$ & 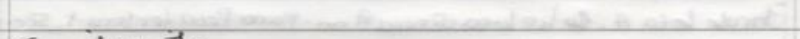 & 10 \\
\hline 4. & 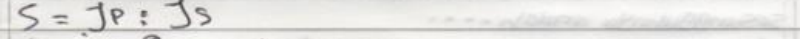 & 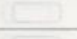 \\
\hline$\square$ & Dik $=1 \mathrm{~s} 8 \mathrm{~cm}=1.500,000$ & 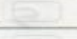 \\
\hline$\square$ & $J P=95,00,000$ & +1 \\
\hline$\square$ & & ( \\
\hline 5 . & 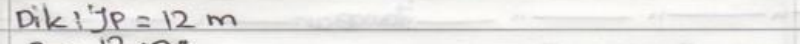 & tans \\
\hline$\square$ & 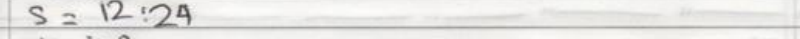 & $2=$ \\
\hline$\square$ & 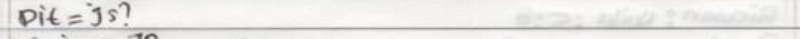 & 100 \\
\hline$\square$ & 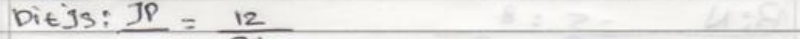 & 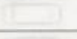 \\
\hline$\square$ & 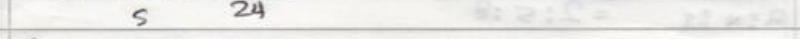 & 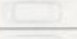 \\
\hline$\square$ & 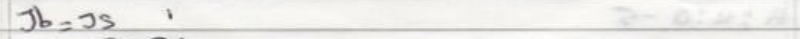 & + \\
\hline$\square$ & 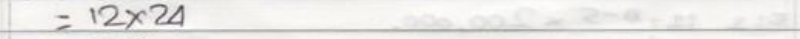 & 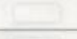 \\
\hline$\square$ & $=522$ & +1 \\
\hline$\square$ & $3=1=$ & 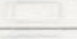 \\
\hline$\square$ & & 10 \\
\hline$\square$ & 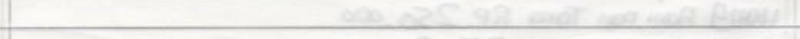 & 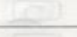 \\
\hline$\square$ & 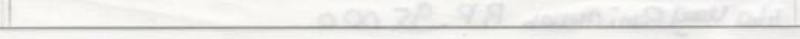 & $+\sqrt{2}$ \\
\hline
\end{tabular}

Gambar 3. Hasil jawaban siswa dengan kategori rendah

\section{SIMPULAN}

Berdasarkan analisis data dari penelitian yang dilakukan serta mengacu pada perumusan masalah pada penelitian ini, dapat disimpulkan bahwa kemampuan pemahaman matematis siswa kelas VII SMP Koperasi Pontianak masih rendah yang ditunjukkan dengan terdapatnya banyak 
kekeliruan penyelesaian soal kemampuan pemahaman matematis khususnya pada indicator mendefinisikan konsep secara tulisan, merepresentasikan suatu konsep dalam bentuk model, diagram, dan symbol, mengidentifikasikan contoh dan bukan contoh suatu perbandingan serta mengubah suatu bentuk representasi ke bentuk lainnya. Dalam penelitian ini memberikan suatu pemikiran yang berhubungan dengan analisis kemampuan pemahaman matematis siswa kelas VII SMP Koperasi Pontianak dalam mempelajari materi perbandingan, maka disarankan kepada: (1) guru yang mengajar materi perbandingan harus memperhatikan siswa dalam proses pembelajaran agar siswa tidak kesulitan dalam mempelajari materi berikutnya. Dalam proses pembelajaran, guru seharusnya memperhatikan tingkat kemampuan siswa agar tujuan yang ingin dicapai dalam memberikan pembelajaran lebih efektif dan siswa yang memiliki kemampuan rendah harus lebih diperhatikan. (2) Penulis berharap agar para peneliti atau calon peneliti dapat meneruskan atau mengembangkan penelitian ini dengan eksperimen maupun penelitian tindakan agar kesulitan siswa teratasi. Para peneliti juga bisa menggali lebih mendalam terkait kemampuan pemahaman matematis siswa dalam mempelajari materi perbandingan khususnya siswa dengan kategori rendah. Hasil penelitian ini dapat menjadi masukan untuk melakukan penelitian yang serupa pada materi lain.

\section{UCAPAN TERIMA KASIH}

Terima kasih diucapkan kepada Lembaga Penelitian dan Pengabdian kepada Masyarakat IKIP PGRI Pontianak atas dana APBS IKIP PGRI Pontianak tahun anggaran 2018 yang diberikan serta IKIP PGRI Pontianak dan SMP Koperasi Pontianak sebagai mitra dalam kegiatan penelitian.

\section{DAFTAR PUSTAKA}

Alan, U. F., \& Afriansyah, E. A. (2017). Kemampuan pemahaman matematis siswa melalui model pembelajaran auditory intellectualy repetition dan problem based learning. Jurnal Pendidikan Matematika, 11(1), 67-78.

Hamalik. 2003. Perencanaan pengajaran berdasarkan pendekatan sistem. Jakarta: PT. Bumi Aksara.

Wibawa, B. (2017). Analysis of mathematics students ability in learning metacognitive strategy type ideal (identify, define, explore, act, look). International Electronic Journal of Mathematics Education, 12(3), 859-872.

Ignacio, N. G., Nieto, L. J. B., \& Barona, E. G. (2006). The affective domain in mathematics learning. International Electronic Journal of Mathematics Education, 1(1), 16-32.

Jonsson, B., Norqvist, M., Liljekvist, Y., \& Lithner, J. (2014). Learning mathematics through algorithmic and creative reasoning. The Journal of Mathematical Behavior, 36, 20-32. 
Kurniadi, G., \& Purwaningrum, J. P. (2018). Kemampuan pemahaman matematis siswa melalui discovery learning berbantuan asesmen hands on activities. Anargya: Jurnal Ilmiah Pendidikan Matematika, 1(1), 8-13.

Malihatuddarojah, D., \& Prahmana, R. C. I. (2019). Analisis kesalahan siswa dalam menyelesaikan permasalahan operasi bentuk aljabar. Jurnal Pendidikan Matematika, 13(1), 1-8.

Ruseffendi, E.T. 2006. Pengantar kepada membantu guru mengembangkan kompetensinya dalam pengajaran matematika untuk meningkatkan CBSA. Bandung: Tarsito.

Susiaty, U. D., Firdaus, M., \& Hodiyanto, H. (2017). Analisis kesulitan belajar mahasiswa program studi pendidikan matematika dalam mempelajari matematika ekonomi. SAP (Susunan Artikel Pendidikan), 1(3).

Wijaya, T. T., Dewi, N. S. S., Fauziah, I. R., \& Afrilianto, M. (2018). Analisis kemampuan pemahaman matematis siswa kelas IX pada materi bangun ruang. UNION: Jurnal Ilmiah Pendidikan Matematika, 6(1). 